Review

\title{
Human Discovery and Settlement of the Remote Easter Island (SE Pacific)
}

\author{
Valentí Rull \\ Laboratory of Paleoecology, Institute of Earth Sciences Jaume Almera (ICTJA-CSIC), C. Solé i Sabarís s/n, \\ 08028 Barcelona, Spain; vrull@ictja.csic.es
}

Received: 19 March 2019; Accepted: 27 March 2019; Published: 2 April 2019

\begin{abstract}
The discovery and settlement of the tiny and remote Easter Island (Rapa Nui) has been a classical controversy for decades. Present-day aboriginal people and their culture are undoubtedly of Polynesian origin, but it has been debated whether Native Americans discovered the island before the Polynesian settlement. Until recently, the paradigm was that Easter Island was discovered and settled just once by Polynesians in their millennial-scale eastward migration across the Pacific. However, the evidence for cultivation and consumption of an American plant- the sweet potato (Ipomoea batatas) — on the island before the European contact (1722 CE), even prior to the Europe-America contact (1492 CE), revived controversy. This paper reviews the classical archaeological, ethnological and paleoecological literature on the subject and summarizes the information into four main hypotheses to explain the sweet potato enigma: the long-distance dispersal hypothesis, the back-and-forth hypothesis, the Heyerdahl hypothesis, and the newcomers hypothesis. These hypotheses are evaluated in light of the more recent evidence (last decade), including molecular DNA phylogeny and phylogeography of humans and associated plants and animals, physical anthropology (craniometry and dietary analysis), and new paleoecological findings. It is concluded that, with the available evidence, none of the former hypotheses may be rejected and, therefore, all possibilities remain open. For future work, it is recommended to use the multiple working hypotheses framework and the strong inference method of hypothesis testing, rather than the ruling theory approach, very common in Easter Island research.
\end{abstract}

Keywords: islands; discovery; settlement; colonization; Easter Island; Rapa Nui; Pacific Ocean; Polynesians; Native Americans

\section{Introduction}

Due to their remoteness and physical isolation, oceanic islands are particularly well suited to study discovery and settlement processes [1]. Easter Island, located in the South Pacific, has been included among the most remote inhabited places on Earth (Figure 1). This, together with its more or less intermediate position between the Polynesian Pacific archipelagos and the South American continent, of contrasting cultural traits, has fostered the interest on when, how, and by whom this tiny island was discovered and initially settled and whether it has experienced significant cultural turnover since then [2-5].

This paper briefly reviews the classical literature on the subject to present the main hypotheses that have been erected and the archaeological, ethnological, and paleoecological evidence used to test them. The paradigmatic outcomes of these studies are then checked against new multidisciplinary evidence collected during the last decade, including genomics, the results of which have challenged and/or enriched former views. The focus is on the discovery and settlement phases and, eventually, on the occasional occupancy between these two events. Postsettlement cultural developments and their possible drivers have already been reviewed by the author elsewhere [6,7]. Finally, it is recommended 
that further studies adopt a multiple working hypotheses framework combined with the strong inference method of hypothesis testing to adequately tackle the inherent complexity of the topic under study [8].

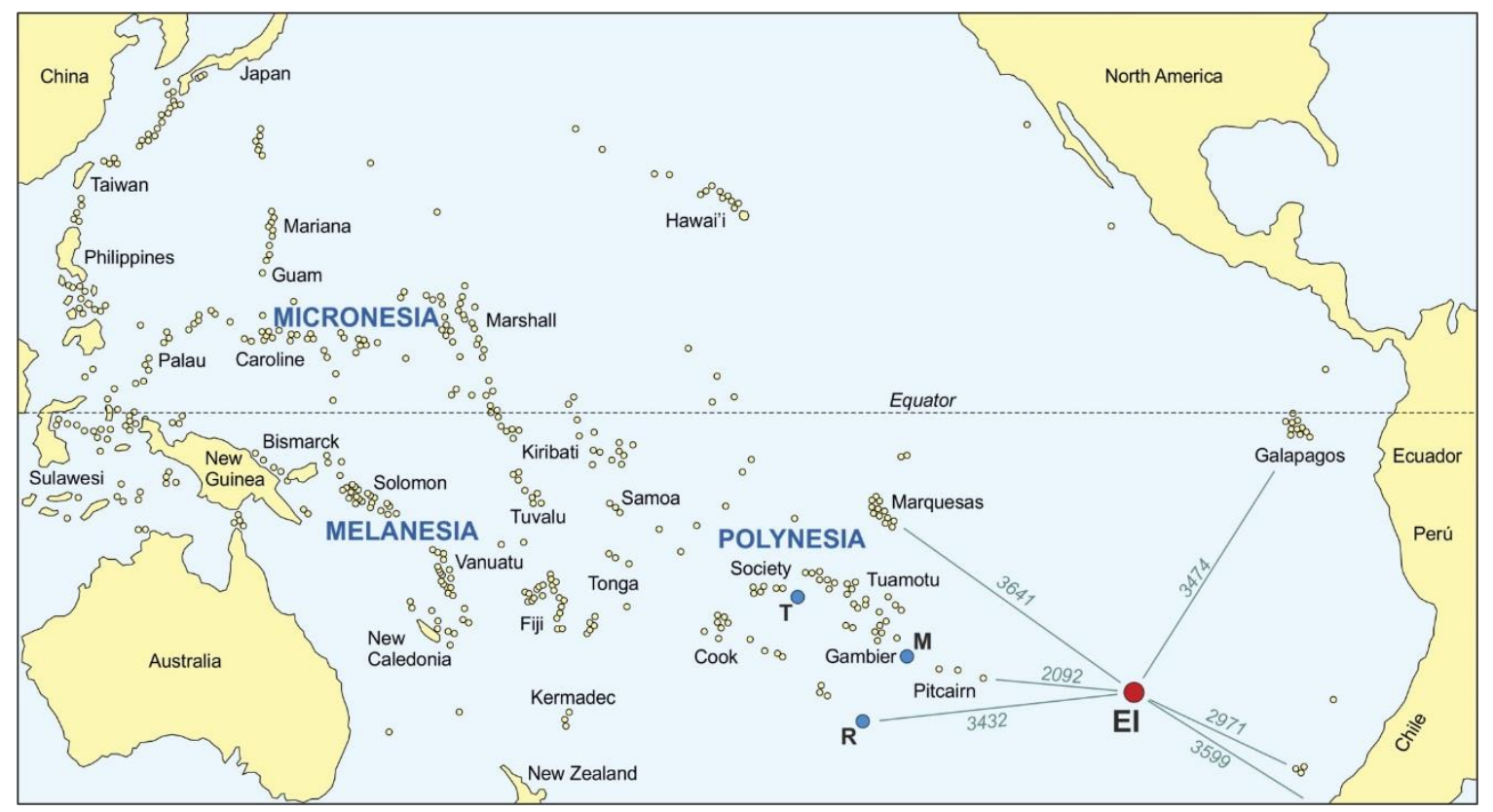

Figure 1. General map of the Pacific Ocean with indication of the main archipelagos including those mentioned in the text. Easter Island (EI) is displayed as a red dot and some significant islands in the context of this paper are highlighted as blue dots (M-Mangareva; R-Rapa Iti; T-Tahiti). The distance between Easter Island and some relevant islands is expressed in $\mathrm{km} \mathrm{[3].}$

\section{The Island Today}

Easter Island is called Rapa Nui by its aboriginal inhabitants, the Rapanui. The name Easter Island (Paasch Eyland, in Dutch) was coined by the first Europeans who arrived to the island, a Dutch expedition commanded by Jacob Roggeveen, on Easter Sunday (5th April) of 1722. The name Rapa Nui (Big Rapa) originated later in the 1860s, and was used by the Tahitian sailors to differentiate the island from a smaller one called Rapa (now Rapa Iti, meaning Small Rapa) (Figure 1). According to the indigenous tradition, the first name of the island was Pito-o-te-Henua (the Navel of the World or the End of the World, depending on the source) but this term is rarely used. In Spanish-the official Chilean language (the island belongs to Chile since 1888) — the name is Isla de Pascua. Easter Island is very small $\left(164 \mathrm{~km}^{2}\right)$ and of triangular shape, owing to the coalescence of three volcanic cones: Terevaka (the highest elevation of the island with $511 \mathrm{~m}$ ), Poike, and Kao (Figure 2). The island is located at about $27^{\circ} 07^{\prime} 09^{\prime \prime} \mathrm{S}$ and $109^{\circ} 21^{\prime} 29^{\prime \prime} \mathrm{W}$, more than $2000 \mathrm{~km}$ apart from the nearest Polynesian islands (Picairn) and $>3500 \mathrm{~km}$ far from the South American Pacific coasts (Figure 1). 


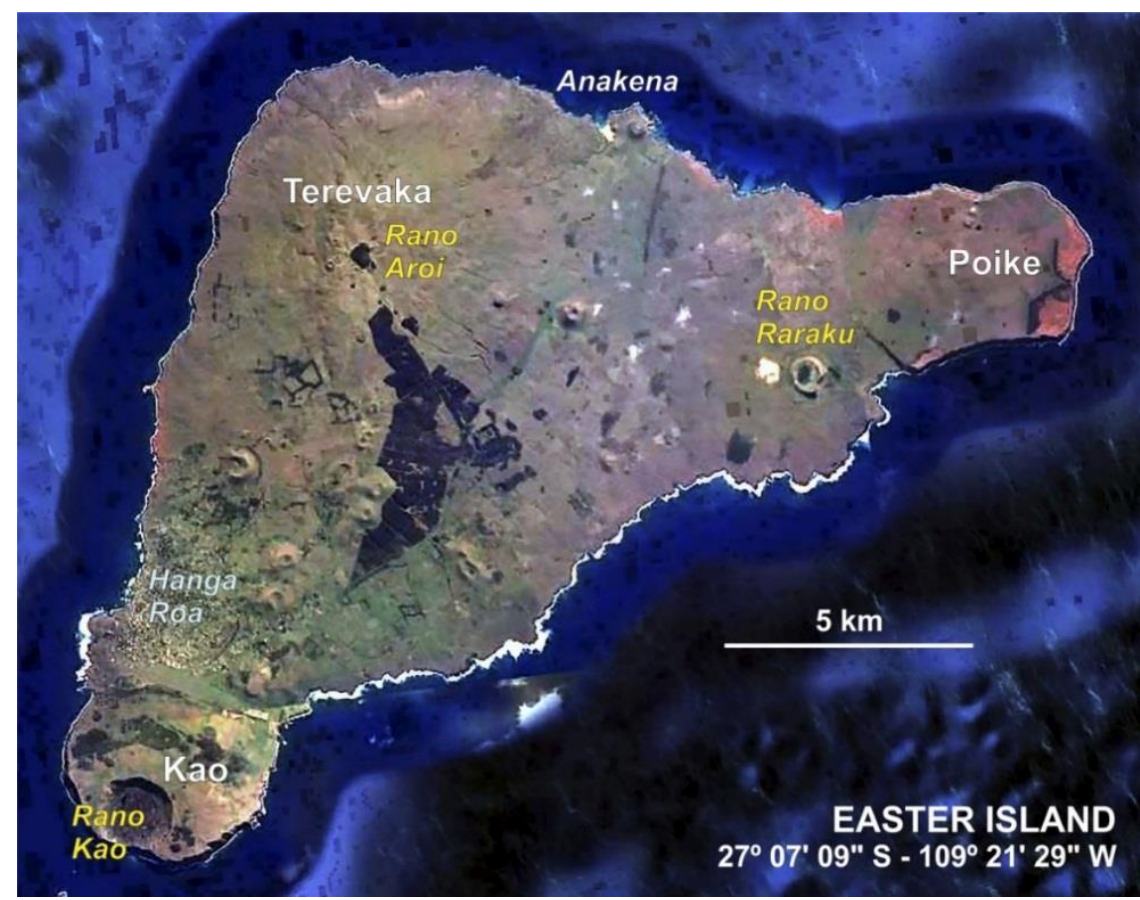

Figure 2. Google Earth view of Easter Island indicating the main features mentioned in the text.

The climate is subtropical oceanic with annual average temperatures of $20-21{ }^{\circ} \mathrm{C}$ and small seasonal variations $\left(2-3^{\circ} \mathrm{C}\right)$. Total annual precipitation is $1200 \mathrm{~mm}$ on average, with a more humid period between April and June (120-140 mm/month) and a drier phase between November and January (70-90 mm/month). There are no permanent water courses on the island due to the high porosity of its volcanic rocks; the only freshwater reservoirs are the ranos, an indigenous name to designate a volcanic crater with permanent water inside, in the form of a lake or a marsh [9]. The biggest one is Rano Kao, with a lake of $>1 \mathrm{~km}$ diameter and ca. $10 \mathrm{~m}$ depth, followed by Rano Raraku (300 m diameter and up to $3 \mathrm{~m}$ depth) and Rano Aroi, with a marsh of ca. $150 \mathrm{~m}$ diameter (Figure 3).

The vegetation is entirely anthropogenic and dominated by grasslands (85-90\% of the surface), forest and shrublands are scare (5\% each), and $\sim 1 \%$ corresponds to crops and ruderal vegetation [10]. The flora is not very rich and most species are introduced. Indeed, of the $>200$ species of vascular plants known, less than a quarter are autochthonous and only four are endemic to the island [11]. This situation contrasts with palynological reconstructions that have documented an island mostly covered by dense and extensive palm-dominated forests during the last $40 \mathrm{kyr}$ BP [12-14]. These forests would have been totally removed in 1400-1600 CE by Polynesian colonizers, the fruit eating rats they introduced to the island, or both $[3,15,16]$. This has been interpreted as the result of the overexploitation of the Island's natural resources and the main cause of the cultural collapse of the ancient Rapanui civilization [3], which has been considered a microcosmic model for the future of the entire planet under the current exploitation practices [17]. This ecocidal hypothesis has been paradigmatic for decades but further studies have challenged this view [5,16,18-20].

At present, Easter Island has about 6000 inhabitants, most of them living on the capital, Hanga Roa. Approximately $40 \%$ of the population is considered to be of Polynesian origin and $60 \%$ is of Chilean origin, although the intense mixing between these two ethnic groups prevents to define a clear separation between them. The indigenous language of Rapa Nui is called vananga and is of Polynesian origin, but is restricted to this island. The different cultures that have established on the island have influenced the original vananga, which has contribution from several languages, notably English, French, Spanish, and Tahitian [21]. 

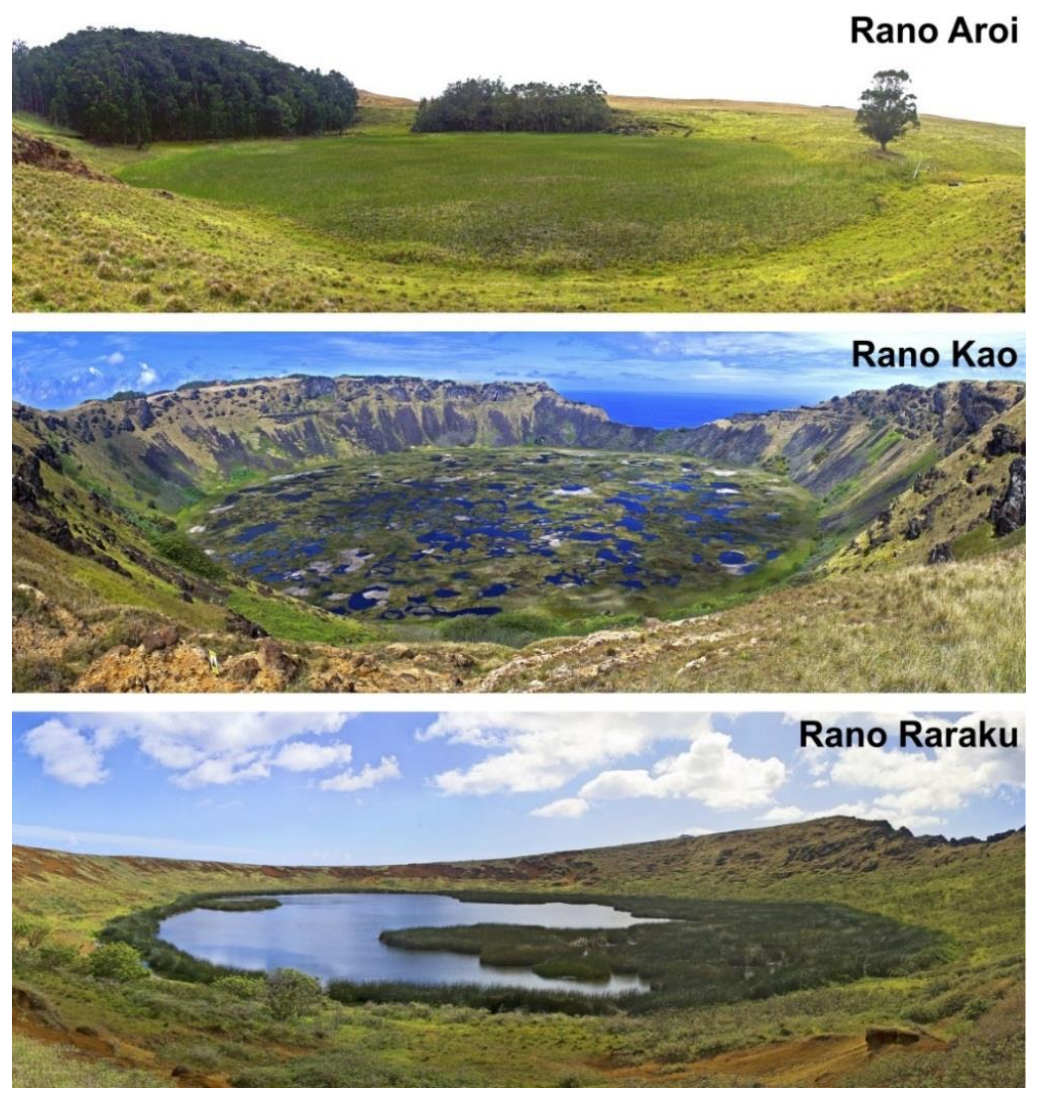

Figure 3. The three permanent waterbodies of Easter Island. Photos: V. Rull.

The island holds an impressive cultural heritage from the ancient Rapanui civilization that, according to the ecocidal paradigm, caused the socioecological demise of the island. The most iconic manifestations of this disappeared civilization are the $>950$ megalithic statues, called moai (Figure 4), carved on the soft volcanic rocks (tuff) of the Raraku crater and transported, by unknown methods, to almost all island's coasts [22]. However this is not the only legacy of that enigmatic civilization, as it has been estimated that a total of 20,000 sites and/or manifestations (in an island of $<170 \mathrm{~km}^{2}$ ) of archaeological interest are still available in their places of origin, including several types of dwellings, petroglyphs, cultivation shelters or landmarks, among others [23]. The whole island has been considered an outdoor museum with many enigmas still to be elucidated.

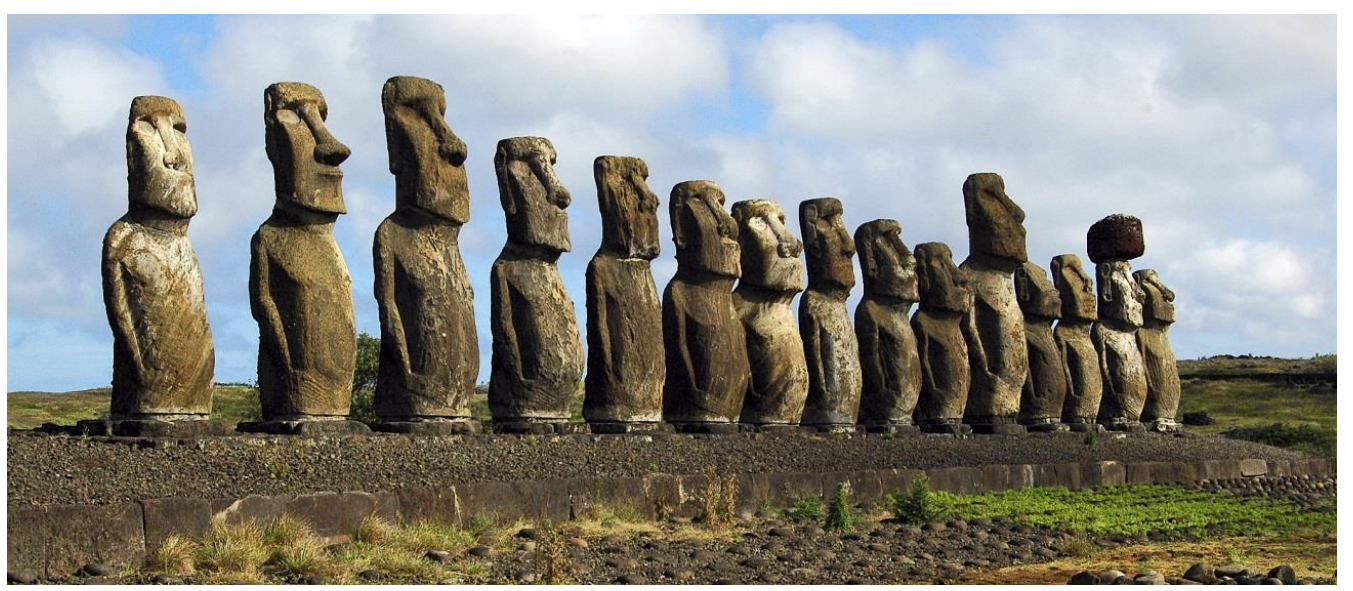

Figure 4. Ahu Tongariki, near Rano Raraku, he largest moai agrupation and ceremonial center of Easter Island. The largest of these 15 moai attains ca. $9 \mathrm{~m}$ high and 90 tons of weight. Photo: N. Cañellas. 


\section{The East-West Debate}

The intermediate position of Easter Island between South America, to the East, and Polynesia, to the West, has fostered a controversy on the geographical origin of Easter Island's discoverers and settlers from either one or another side of the Pacific Ocean. A brief historical account is provided to the following on how this debate has proceeded using mainly ethnological and archaeological evidence. More extensive and detailed reviews are available elsewhere [2-5,24-27].

\subsection{Rapanui Mythology}

The first hypothesis on the origin of the Rapanui civilization emerged from Rapanui's oral tradition and, hence, it should be taken with great care [3]. According to the Rapanui legend, the founders of this civilization arrived from the west by boat and landed at Anakena beach (Figure 2). These pioneers were commanded by Hotu Matu'a and their homeland was a hypothetical Polynesian island called Hiva. These first colonizers brought all what they needed to settle the island (food, tools, plants, and animals) and settled near Rano Raraku, from where they spread across the island. This legend does not specify a particular chronology for the arrival of the Polynesian settlers. As any legend based on oral tradition, there are several versions and a variable set of details according to the person who tells the story but there is a general agreement in the geographical origin. On the basis of the Rapanui oral tradition, earlier Easter Island ethnologists, such as Katherine Routledge or Alfred Métraux, located the legendary island of Hiva in the Marquesas Islands or in the Gambier Islands, specifically on an island called Mangareva (Figure 1) [24,25]. It should also be noted that modern Rapanui have an indisputable Polynesian origin and, hence, they refer to the origin of their own culture. In the Rapanui mythology, Hotu Matu'a and their followers were both the discoverers and the first settlers of Easter Island.

\subsection{South American Origins}

In 1803, the Spanish missionary Joaquín de Zúñiga suggested that the predominant winds and marine currents seamed favorable for navigating from South America to Polynesia. During the same century, several analogies were established between the Easter Island statues and those from Native American cultures of Bolivia and Peru [3]. These observations encouraged the Norwegian explorer Thor Heyerdahl to demonstrate that Easter Island was first discovered by Native Americans, before the arrival of the Polynesian culture that founded the Rapanui civilization. The famous Kon-Tiki expedition was launched for this purpose in 1947. Using a simple raft with a single sail, Heyerdahl and five other men navigated from Peru to the Tuamotu Islands in 101 days (Figure 5) with only the aid of the winds and the marine currents, thus supporting the hypothesis of Zúñiga [28]. Heyerdahl concluded that Easter Island would have been discovered in this way by Native American cultures and organized a fieldwork campaign (1955-1956) to the island to collect evidence in support of this idea. He found, for example, that some plants (notably the sweet potato; Ipomoea batatas) were considered to be introduced from South America and their names (kumara, in the case of sweet potato) were also of Native American origin. He also noted similarities between many tools and constructions, including the moai and some petroglyph representations, with potential Incaic and pre-Incaic counterparts from South America [29].

The underlying hypothesis of Heyerdahl was that Native Americans were the discoverers of Easter Island by $400 \mathrm{CE}$ and the Polynesians arrived later and eradicated the Amerindian culture. Heyerdahl linked this view with a Rapanui legend about a war between two groups called the "short-ears" and the "long-ears", where the first won and exterminate the enemies. The chronology was based on a single radiocarbon date and was called in question later and considered too old [30]. The scientific community did not take Heyerdahl's ideas too seriously arguing that he was so attached to his theories that he was neither objective nor rigorous in the analysis of evidence [3]. Perhaps the main merit of Heyerdahl was that, for the first time, he disentangled discovery from settlement, in a cultural sense, 
and introduced the possibility of arrival and interaction of both Polynesian and Amerindian cultures on Easter Island.

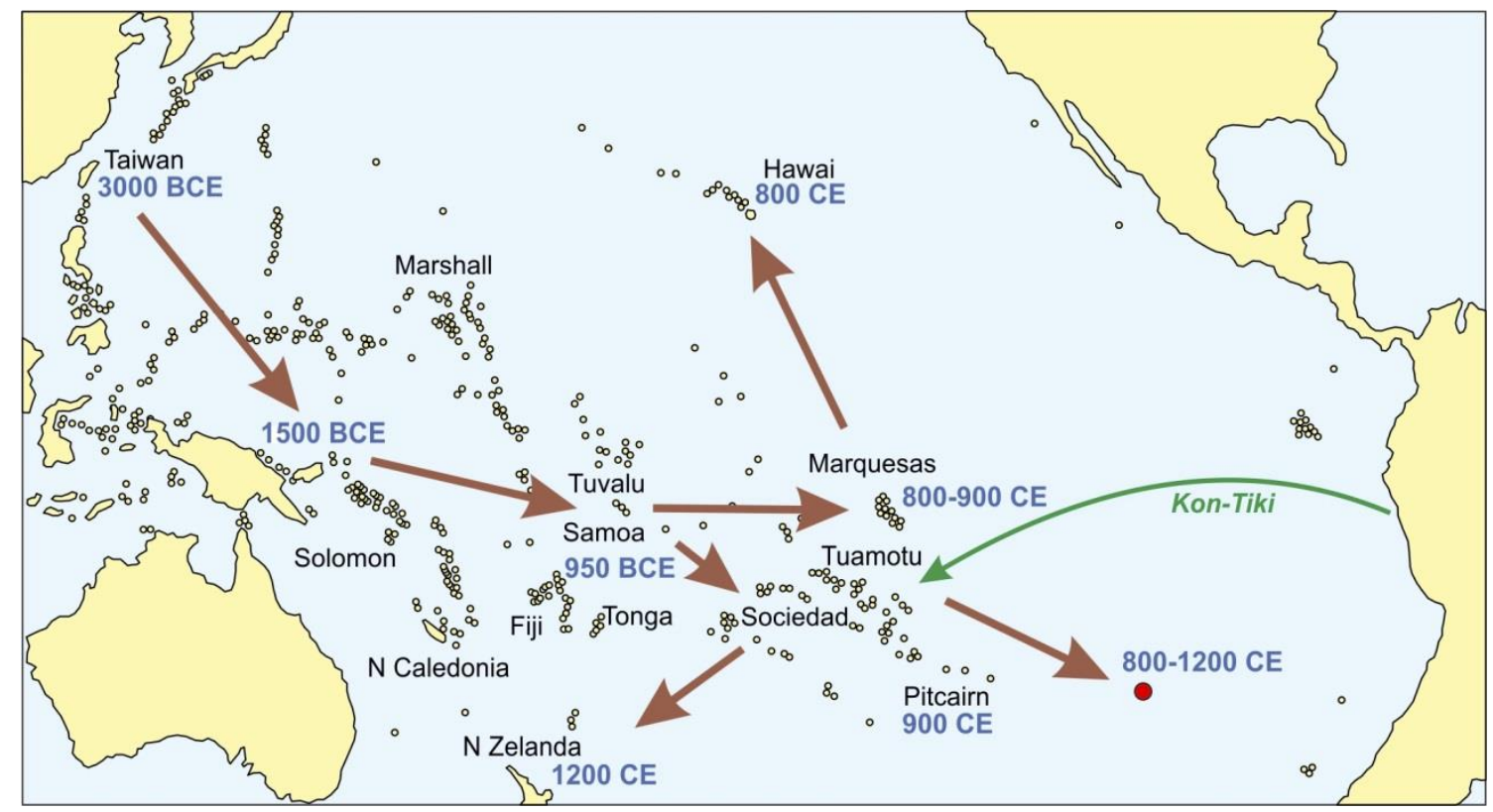

Figure 5. Peopling of the Pacific from East Asia, according to Kirch [31]. The green arrow is the approximate trajectory of the Kon-Tiki experition [28].

\subsection{Polynesian Origins}

Most evidence provided by Heyerdahl to defend his theory of Native American discovery was reanalyzed by Flenley and Bahn [3] to support the contrary hypothesis, that is, the Polynesian discovery and settlement, coinciding with the Rapanui legend. These authors highlighted that the winds and currents that favor the East-West navigation are not constant but vary seasonally. They also noted that the "El Niño" phenomenon, which occurs every four years, stops or reverts the oceanic circulation thus favoring West-East navigation. Furthermore, navigation skills were very different at both sides of Easter Island. Polynesians were experienced sailors who have colonized most of the Pacific islands and archipelagos for millennia in a West-East direction (see below). Their boats were highly hydrodynamic and very efficient and could be moved by wind and oars, very different to the rudimentary Heyerdahl's Kon-Tiki raft.

Regarding plants of South American origin and their names, these would have been introduced after the European contact. According to Flenley and Bahn [3], the Rapanui art can also be considered of Polynesian origin. For example, the moai and the tools used for their carving may be related to similar representations from Mangareva (the hypothetical Hiva of the Rapanui legend, see above) and adjacent islands. The same is true for the petroglyphs, whose images are common in other Pacific island, for example, Hawaii or New Zealand. Other evidence come from physical anthropology, specifically from skeletons found in the island's excavations corresponding to the ancient Rapanui civilization. The skull biometry and the dental patterns, two characters commonly used in human phylogeny, were also Polynesian in origin, probably from the Marquesas or the Tuamotu Islands (Figure 1).

Flenley and Bahn [3] dismissed the Native American discovery and concluded that Easter Island was colonized only from Eastern Polynesia, probably from the Marquesas Islands, via Mangareva (Figure 1). Based on palynological reconstructions using radiocarbon-dated lake sediments [13,14], these authors found that forests started to decline at about $800 \mathrm{CE}$ and considered this as the indication of the initial Polynesian settlement, under the hypothesis of anthropogenic deforestation. Using archaeological evidence, other authors suggested that the initial settlement of the island took place 
between 800 and $1000 \mathrm{CE}$ and ceremonial sites with worked stones were erected later, sometime between 1100 and 1200 CE [30]. This view is consistent with the Rapanui mythology and also with the current conception of the human colonization of Pacific islands, which is briefly summarized in the following.

\subsection{Peopling of the Pacific}

In a Pacific context, the colonization of Easter Island was one of the last steps of a West-East spreading process (Figure 5) initiated when one or several groups of Taiwanese sailors colonized the Philippines by $5000 \mathrm{yr}$ BP (3000 BCE) [31]. The next step was the colonization of the Bismark Islands, north of New Guinea, by 1500 BCE. This was a fundamental stage because it implied the disconnection from the original Taiwanese culture and the development of a new culture known as Lapita, which was the seed of all Polynesian cultures.

The Lapita culture experienced a rapid expansion reaching Tonga and Samoa (Western Polynesia) by 950 BCE, followed by a long pause of 2000 years, before the expansion towards Eastern Polynesia. The archipelagos of Society, Tuamotu, and Marquesas, as well as the Mangareva Island, were not colonized until 600 to $900 \mathrm{CE}$. The last expansion wave started from these archipelagos in three different directions-Hawaii (800 CE), Easter Island (800 CE), and New Zealand, the last Polynesian Island to be colonized-by 1200-1300 CE. Some authors have presented evidence of later dates for this last colonization wave, including Easter Island, which would have occurred between 1200 and 1300 CE [32]. This coincides with the oldest dated archaeological materials from the Anakena beach (the landing site of Hotu Matu'a and his group, according to the Rapanui tradition), which are dated between 1200 and 1400 CE [33].

According to Nunn [34], the last colonization wave, including the discovery and settlement of Easter Island, took place during the Medieval Warm Period (750-1250 CE), characterized by warm and dry conditions with reduced storminess, low interannual variability, and rising sea levels, perhaps above present-day ones. Aridity would have stimulated the search for new islands to live, and climatic stability and increased sea levels would have provided better conditions for long-distance navigation. This is supported by the larger amount of interisland interactions documented during the Medieval Warm Period, in comparison with the Little Ice Age (1350-1800 CE), when long-distance voyaging ceased coinciding with increased variability in trade winds, increased storminess and perhaps increased dust from volcanic eruptions [34].

This general picture is the current paradigm but there are still some points that should be clarified before dismissing any Native American influence on Easter Island before the European contact, which signified the first worldwide exposure of the island and its inhabitants. Perhaps the most important of these pending issues is the presence, on the island, of the sweet potato (Ipomoea batatas), which was considered by Flenley and Bahn as "The only remaining possible botanical link between the island and the South American mainland ... " [3] during the Rapa Nui prehistory, i.e., before the European contact.

\section{The Sweet Potato Enigma}

The sweet potato, which in Rapanui is known by its Amerindian name of kumara, originated in tropical America and was domesticated $>6000$ years ago, owing to the nutritional properties of its tuberous roots $[35,36]$. There is evidence of its presence on Easter Island long before European contact (1722 CE), even before Europe-America contact (1492 CE). Therefore, it is likely that the ancient Rapanui used this American plant before Europeans knew it. The oldest Polynesian record of sweet potato consisted of carbonized soft tissues found on the Cook Islands (Figure 1), dated to ca. $1000 \mathrm{CE}$ [37]. The occurrence of sweet potato remains throughout Polynesia in archaeological sites of similar ages has suggested that cultivation and consumption of this plant was common and widespread long before European contact. On Easter Island, carbonized fragments of sweet potato were found on archaeological sites dating back $1-3$ centuries before European contact $[38,39]$. It has 
been considered that the sweet potato was the main food source during the flourishment of the ancient Rapanui society, which occurred between approximately 1200 and 1500 CE [4,40]. How could the sweet potato be present on Easter Island before the Europeans arrived in America? Hypothetically, four main possibilities exist-the long-distance dispersal hypothesis, the back-and-forth hypothesis, the Heyerdahl hypothesis, and the newcomers hypothesis—-which are presented at following.

\subsection{Long-Distance Dispersal Hypothesis}

According to the long-distance dispersal hypothesis, sweet potato seeds could have reached Easter Island by nonhuman means [3], including birds, wind, or rafting (attached to sea-drifting materials). An analysis of the so called dispersal syndromes, based on seed morphology, concluded that birds would have been the dispersal agents of $75 \%$ of the Easter Island's original flora and the remaining $25 \%$ would have been dispersed by water drift; none of the species was considered to be anemochore (dispersed by wind) [41,42]. According to Zizka [11], the sweet potato was anthropocore (human dispersal) and, therefore, the long-distance dispersal by others means was considered unlikely. In addition, dispersal modeling suggested that the probability of long-distance seed dispersal from America and further successful establishment in Polynesia was very low [43].

\subsection{Back-and-Forth Hypothesis}

The back-and-forth hypothesis was based on the possibility that Easter Polynesians travelled to South America in pre-Columbian times and came back with the sweet potato, thus facilitating its spread over Polynesia [44]. Based on archaeological, ethnobotanical, and linguistic data, it was suggested that the kumara variety of the sweet potato could have dispersed from the Peru/Ecuador coasts to the Marquesas-Tuamotu society region (1000-100 CE), and then rapidly transferred to Hawaii, Easter Island, and New Zealand (1150-1250 CE) [45-47]. Remarkably, the Native American name (kumara) has been preserved in Easter Island and New Zealand and their derivatives (koumara, kumala, kumal, kuma'a, 'uumara, kuuara, 'uala, umala, and others similar) occur across the entire Pacific, from the Micronesian Mariana Islands (Figure 1) to Easter Island [45]. Historical reports demonstrate that other sweet potato varieties (camote and batata) were transported to the West Pacific by European traders, after the Europe-America contact.

Currently, the back-and-forth option is the more accepted hypothesis by archaeologists and ethnobotanists working on this subject. This hypothesis implies that Polynesians arrived in America prior to Europeans, a view that is under discussion [48,49]. Jones et al. [49] compiled the material, linguistic, biological, mythological, nautical, chronological, and physical anthropological evidence in support of the pre-Columbian presence of Polynesians in America, and suggested that such contact could have occurred repeatedly between approximately 700 and $1350 \mathrm{CE}$ by three main regions: southern Chile, Ecuador/Peru, and California (Figure 1). According to these authors, Polynesians did not alter the general cultural development of Native Americans, but introduced new technologies and domesticates that affected the subsistence practices of local populations.

\subsection{Heyerdahl Hypothesis}

The Heyerdahl hypothesis is based on the already mentioned possibility of Native Americans discovering Easter Island long before the Polynesian arrival and carrying the sweet potato with them. As it has been discussed above, this possibility was considered very unlikely by the defenders of the unique Polynesian discovery and colonization but recent evidence has been put it back on the table.

\subsection{Newcomers Hypothesis}

In theory, it is also possible that Native Americans arrived to Easter Island after its Polynesian colonization, an option that has not been considered in the classical literature but deserves further examination in light of recent evidence. This option has two hypothetical possibilities, one is that Native Americans arrived by their own, and the other is that they were transported to Easter Island by 
Polynesians in their return from America. The first possibility is similar to the Heyerdahl hypothesis but with different timing, whereas the second option implicitly includes the back-and-forth hypothesis.

\section{New Evidence}

Most evidence discussed above was provided by archaeological, ethnological, ethnobotanical, historical, and paleoecological research. During the last decade, the spectacular development of molecular phylogenetic and phylogeographic tools has increased the body of evidence to test the hypotheses about the colonization of Easter Island. These analyses have been applied to humans, thus providing direct evidence on the origin of settlers, and also to some plants and animals intimately linked to human life, as indirect evidence for human migrations. Other analyses carried out recently include physical anthropological techniques such as craniometry and paleodietary analysis. Finally, new paleoecological records have also provided evidence on plants associated to human activities, as indicators of potential human migrations.

\subsection{Sweet Potato Phylogeography}

Molecular DNA phylogenies have provided evidence for sweet potato dispersal across the Pacific Ocean. The first attempts yielded incomplete results, mainly due to insufficient geographical sampling but a recent study that included the Neotropics and the entire Pacific Ocean was more informative. In this study, Roullier et al. [50] genetically differentiated the kumara lineage and demonstrated that this was the sweet potato variety that spread over the whole Pacific from the South American coasts of Peru/Ecuador. The spreading of the kumara lineage occurred before the introduction of the camote and batata lineages, that is, during pre-Columbian times, but the study did not provide a specific chronology [50]. The authors of this study suggested that Polynesian sailors were the most likely agents of transport and diffusion of the kumara lineage from South America to Oceania, thus supporting the back-and-forth hypothesis.

A more recent molecular phylogenetic study of the genus Ipomoea [51] found that Ipomoea littoralis, a Pacific species absent from America, diverged from its sister species, the American I. lactifera, more than one million years ago, long before the human colonization of the Pacific. The authors suggested that I. littoralis reached the Pacific by long-distance dispersal of their seeds. The same occurred with I. tuboides, which is endemic to Hawaii but belongs to a clade dominated by Mexican species. All these species are closely related to the sweet potato (I. batatas) and have similar seeds, fruits, and dispersal biology. Therefore, the authors of the study suggested that long-distance dispersal cannot be dismissed as a potential means of sweet potato to reach the Pacific islands in pre-Columbian times [51].

In support to the long-distance dispersal hypothesis of I. batatas, the same study analyzed a specimen of sweet potato collected on the Society Islands (Figure 1) by Captain Cook's expedition in $1769 \mathrm{CE}$. The dated phylogeny of this specimen showed that it diverged from its closest relative during pre-human times between approximately 110,000 to 140,000 years ago. Again, this was interpreted in terms of long-distance dispersal, a mechanism that was considered common in the genus Ipomoea [51]. These conclusions rely on phylogenetic dating, one of the more controversial steps of molecular phylogenetic analyses, which is in constant development. Given previous experiences, it would not be surprising that further studies find different divergence ages.

\subsection{Physical Anthropology}

The demonstration that sweet potato was an important food source for Rapanui in pre-Columbian times came from the finding of starch grains of Ipomoea batatas in the dental calculus of Rapanui skeletons dated to $1330 \mathrm{CE}$ [52]. However, this did not resolve the enigma of whether the sweet potato was carried to Easter Island by Native Americans or by Polynesians in back-and-forth travels. Genome-wide molecular analysis of a sample of 27 native Rapanui without known foreign ancestry revealed a predominantly Polynesian origin ( $76 \%$ of the genome), with an early contribution from 
Native Americans (8\%), dated to 1280-1495 CE, and a later European contribution (16\%), occurred from 1850 CE [53].

This suggested the presence of Native Americans on Easter Island shortly after Polynesian settlement and long before the Europe-America contact (newcomers hypothesis) but, once more, it was not possible to know whether these Native Americans arrived by their own or were transported by Polynesians in their eventual return from South America (back-and forth hypothesis) [54]. Considering the navigation skills of these two cultures, the back-and forth hypothesis seems more plausible. As it has been noted above, Polynesians were sophisticated sailors who colonized the entire pacific from West to East. One more step reaching South America would have not been surprising. Native Americans, on the contrary, used to navigate near the continental coasts, and the longest trip known was to the Galapagos Islands, situated ca. $1000 \mathrm{~km}$ offshore [3].

A more recent study analyzed the DNA of five skeletons from an archaeological site on the Anakena beach dated to 1445-1624 CE (pre-European contact) to 1815-1945 CE (post-European contact) [55]. No American ancestry was found for any of them and the authors suggested that contemporary American ancestry found in previous studies $[53,54]$ was not present in the island prior to European contact and may be due to contacts in more recent history. However, the extrapolation of results obtained in such a small sample from a single archaeological site to the entire island and the whole ancient Rapanui culture is unwarranted.

Perhaps the most convincing evidence of Polynesians travelling to South America (back-and-forth hypothesis) was the finding of chicken bones of Polynesian origin as old as ca. 1300-1400 CE on the Chilean coast [56]. The genome of these bones was identical to chicken bones found at prehistoric archaeological sites from Tonga (Figure 1), dated to 2000-1550 yr BP. A further phylogenetic study of ancient and modern Polynesian chickens did not find early South American ancestry and questioned chickens as providers of evidence for Polynesian-South America pre-Columbian contact [57]. This study demonstrates that the chickens analyzed have no American ancestry but they do not invalidate previous records of Polynesian chickens in South America [56].

Other evidence for the presence of Polynesians in America before the European contact was the craniometric analysis of pre-Columbian skeletons found on a $30 \mathrm{~km}$ offshore Chilean island, which suggested that they may be of Polynesian origin [58]. Two human skulls from Brazilian indigenous were found to be of Polynesian origin with no detectable American components in their DNA [59]. The relatively recent age of these skulls prevented unequivocal attribution of its presence in South America to pre-Columbian voyaging from Polynesia but the authors of the study did not rule out this possibility.

\subsection{Paleoecology}

Recent paleoecological surveys have also provided new evidence useful to test the hypotheses about Easter Island discovery and settlement. One of the main advantages of paleoecology is that it provides evidence from pre-settlement times, and is thus able to test hypotheses on discovery and occasional occupancy events [60]. In addition, paleoecological records may also inform on natural conditions prior to human discovery. On Easter Island, archaeological records begin with Polynesian settlement, between about 800-1200 CE onwards, but paleoecological records preserved in the sediments of Rano Aroi, Rano Kao, and Rano Raraku (Figure 3) extend to the last ca. 40 kyr BP [61]. In this specific case, finding pollen of plants associated with human activities, notably the sweet potato, would be especially helpful. Charcoal records, as fire proxies, and/or forest clearing events could also be useful as indirect indicators but their anthropogenic character should be demonstrated by other independent evidence.

Although the sweet potato has been extensively cultivated on the Pacific during the last millennium, no fossil palynological evidence exists for this fact, as the pollen of Ipomoea batatas is rare or absent in sediments from Pacific islands. This has prevented a reconstruction of the dispersal history of this plant across the Pacific. The paucity of sweet potato pollen in sedimentary records is 
likely due to the strict entomophilous pollination, which involves low pollen production and poor wind dispersal, and the low preservation capacity due to the high susceptibility of this pollen to physicochemical degradation [62]. The better-preserved remains of sweet potato seem to be starch grains, which are found even on dryland soils, although identification is not always unquestionable due to the similarity with starch grains from others cultivated plants such as Alocasia macrorrhiza (elephant ear taro) and Tacca leontopetaloides (Polynesian arrowroot) [63,64].

On Easter Island, the first records of Ipomoea batatas pollen were dubious due to the bad preservation of the fragments found [65], but recent works confirmed the presence of sweet potato pollen in lake sediments. Horrocks et al. [66] found this pollen within the Rano Kao sediments (Figure 3), slightly below a radiocarbon date of $377 \pm 30{ }^{14} \mathrm{C}$ yr BP $(1460-1630 \mathrm{CE})$. Starch grains identified as cf. Ipomoea were found in deeper sediments of the same lake, but the occurrence of age inversions prevented the assignment of a specific date to them. The same authors reported the occurrence of Ipomoea batatas pollen in the sediments of Rano Raraku (Figure 3), close to a sample dated to $587 \pm 30{ }^{14} \mathrm{C}$ yr BP (1320-1440 CE) [67]. Again, cf. Ipomoea starch was found on apparently older, but of uncertain age, sediments. These findings strongly suggest that sweet potato were cultivated on Easter Island about three or four centuries before the European contact, but the evidence is not sufficient to differentiate between the back-and-forth or the newcomers hypotheses. Using the argument of navigation skills, the first possibility would be favored.

Another plant of American origin linked to human activities whose pollen has been recently identified in prehistoric lake sediments from Easter Island is Verbena litoralis (locally called puringa), a ruderal species eventually used for medical purposes. Today, the plant is widespread across the island as a weed and is considered to have been introduced during the last centuries [11]. However, the pollen of this species (identified by comparison with present-day representatives collected around Rano Raraku) appeared in sediments dated to approximately $450 \mathrm{BCE}$ and increased to become an important component of the pollen spectra from that date until the present [68]. The Verbena pollen appeared in an almost continuous and coherent, i.e., free of age inversions, Rano Raraku sedimentary sequence representing the last two millennia.

The first Verbena occurrence was found slightly below a radiocarbon date of $2120 \pm 30 \mathrm{yr}$ BP (200 to $50 \mathrm{BCE}$ ) and the increase leading to present-like values occurred around another radiocarbon date of $1180 \pm 30 \mathrm{yr}$ BP (790 to $990 \mathrm{CE}$ ), which includes the oldest dates proposed for the Polynesian settlement $[3,30]$. The trends of the Verbena pollen paralleled those of grasses and charcoal and were opposite to the palm pollen trends, which suggested that forest clearance would have started approximately two millennia ago and accelerated by 800-1000 CE [68]. According to this, Verbena litoralis was already present when the Polynesians settled Easter Island and low-intensity deforestation, probably by fire, was already in progress. The incoming of Polynesians would have exacerbated forest clearing and the expansion of grasses and Verbena.

The possibility of early, pre-settlement deforestation by fire was already suggested by Butler and Flenley [69]. Working in the Rano Kao sediments, these authors found a significant palm forest decline associated to a sharp charcoal increase, suggestive of forest clearing by fire, at about 1900-1850 cal yr BP. They discussed the possibility of this forest disturbance to have been due natural causes (climate, volcanism). However, the rarity of lighting in Pacific islands and the absence of volcanic ash in the Kao sediments led them to seriously considered the possibility of human intervention. Moreover, the charcoal never deceased to former values indicating continuous disturbance. Butler and Flenley concluded that: " ... the most interesting feature of the diagram is the interpretation that human disturbance began around $1900 \mathrm{BP}$ (c. AD 100), and continued thereafter, perhaps varying in intensity but never ceasing" [69].

These two palynological surveys on Rano Raraku and Rano Kao $[68,69]$ coincided in suggesting a millennial-scale forest disturbance by fire, possibly of anthropogenic origin, which may imply human presence on Easter Island since $450 \mathrm{BCE}$ or $100 \mathrm{CE}$. The coincidence of Verbena litoralis pollen with charcoal trends in Raraku may suggest that Native Americans would have been among these early 
colonizers, which would support the Heyerdahl hypothesis, except for timing. The low fire incidence and gentle forest decline recorded in Raraku until 800-1000 CE may indicate low human pressure until the Polynesian arrival. The whole picture may be consistent with a Native American discovery of the island and a long period of occasional occupancy (either by Native Americans or Polynesians, or both) until the full Polynesian settlement. The absence of archaeological evidence prior to this settlement could be due to its paucity, owing to occasional occupancy, and/or to the ensuing full Polynesian occupation of the island.

\section{Conclusions and Final Remarks}

According to the classical literature based on archaeological, ethnological, and paleoecological evidence, Easter Island was discovered and settled just once by Polynesians, likely from the Marquesas or the Gambier Islands, specifically Mangareva. This is in agreement with the Rapanui oral tradition and would have occurred between 800 and $1200 \mathrm{CE}$, depending on the author. However, the finding of sweet potato (Ipomoea batatas) remains long before European contact (1722 CE), even before the Europe-America contact (1492 CE), challenged this classical view and opened new perspectives for the colonization of this remote island. This American plant was found to be extensively cultivated for human consumption in the Polynesian archipelagos before these dates and was considered to be crucial for the flourishment of the ancient Rapanui civilization. The arrival of this plant to Polynesia, including Easter Island, before the Europeans suggested four main hypotheses that affect the classical view of discovery and settlement of this island.

According to the long-distance dispersal hypothesis, the seeds of sweet potato could have arrived from America to Polynesia transported by wind, rafting, or birds. Another possibility is that Polynesians discovered America before the Europeans and transported the sweet potato in their return (back-and-forth hypothesis). Easter Islanders could have travelled to America by themselves or the plants could have been introduced to the island by Polynesian settlers. Finally, Native Americans could have travelled to Easter Island by themselves carrying the sweet potato either before (Heyerdahl hypothesis) or after (newcomers hypothesis) the Polynesian settlement. These hypotheses have been discussed in this review in light of the evidence provided during the last decade by molecular DNA phylogeography, physical anthropology (DNA and microfossil analysis), and new paleoecological findings.

The long-distance dispersal hypothesis found some support on DNA phylogeographies of sweet potato. The back-and-forth hypothesis was also supported by other phylogeographic studies of this species and also by physical anthropology (dietary, DNA, and craniometric analysis of modern and ancient Rapanui), DNA analysis of domestic Polynesian animals (chickens), and paleoecological analysis involving the finding of Ipomoea batatas pollen in the island before $1492 \mathrm{CE}$. Some of these studies strongly supported the discovery of America by Polynesians before the Europe-America contact but failed to differentiate between the back-and-forth and the newcomers hypotheses. Finally, the Heyerdahl hypothesis, which was officially dismissed for long time, was revived by the finding of pollen from another American species-Verbena litoralis-long before the purported Polynesian colonization. In summary, some hypotheses are more supported than others by the evidence collected during the last decade but there is no conclusive evidence to reject none of them. Therefore, in terms of Easter Island's discovery and settlement, all possibilities remain open.

The discovery and settlement of Easter Island provides one more example of the application of a multiple working hypotheses framework combined with the strong inference method of hypothesis testing [8]. The classical view of a single discovery and settlement event by Polynesians could be considered the ruling theory (sensu Chamberlin [70]) that directed research until new observations put it into question. This fostered the incoming of new possible explanations to be tested with further studies. In this case, four main hypotheses were selected and tested using a diversity of methods, including newly developed analysis tools. In this way, the debate was enhanced from a simple dual 
controversy between the defenders and the opponents of the ruling theory, to become a truly multiple hypotheses discussion.

In this framework, hypotheses are not necessarily excluding, as it occurs in the ruling-theory scheme, and proposals may be complementary. Using the strong inference method [71], based on Popperian logics [72], to dismiss any of these existing hypotheses, it should be falsified using empirical evidence. Contrary to the dual excluding approach, supporting a given hypothesis does not necessarily mean rejecting the others. In the case of the discovery and settlement of Easter Island, none of the existing hypotheses may be rejected with the available evidence. In principle, the hypotheses proposed to date are not necessarily excluding and it is possible that elements of most or all of them could be retained for a sound explanation. It is also possible that new challenging evidence may appear that change the current state of the art, a common feature in scientific research.

Conflicts of Interest: The author declares no conflict of interest.

\section{References}

1. Gillespie, R.G.; Clague, D.A. Encyclopedia of Islands; University California Press: Berkeley, CA, USA, 2009.

2. McCall, G. Rapanui. Tradition and Survival on Easter Island; University Press Hawaii: Honolulu, HI, USA, 1981.

3. Flenley, J.; Bahn, P. The Enigmas of Easter Island; Oxford University Press: Oxford, MS, USA, 2003.

4. Fischer, S.R. Island at the End of the World. The Turbulent History of Easter Island; Reaktion Books: London, UK, 2005.

5. Hunt, T.; Lipo, C. The Statues that Walked. Unraveling the Mystery of Easter Island; Free Press: New York, NY, USA, 2011.

6. Rull, V. Natural and anthropogenic drivers of cultural change at Easter Island: Review and new insights. Quat. Sci. Rev. 2016, 150, 31-41. [CrossRef]

7. Rull, V. La Isla de Pascua. Una Visión Científica; CSIC-La Catarata: Madrid, Spain, 2016.

8. Rull, V. Strong Fuzzy EHLFS: A general conceptual framework to address past records of environmental, ecological and cultural change. Quaternary 2018, 1, 10. [CrossRef]

9. Herrera, C.; Custodio, E. Conceptual hydrological model of volcanic Easter Island (Chile) after chemical and isotopic surveys. Hydrogeol. J. 2008, 16, 1329-1348. [CrossRef]

10. Etienne, M.; Michea, G.; Díaz, E. Flora, Vegetación y Potencial Pastoral de la Isla de Pascua; Facultad Ciencias Agrarias, Veterinarias y Forestales Universidad Chile: Santiago de Chile, Chile, 1982.

11. Zizka, G. Flowering Plants of Easter Island; Palmarum Hortus Francofurtensis: Frankfurt am Main, Germany, 1991.

12. Flenley, J.R.; King, S. Late Quaternary pollen records from Easter Island. Nature 1984, 307, 47-50. [CrossRef]

13. Flenley, J.R.; King, A.S.M.; Jackson, J.; Chew, C. The Late Quaternary vegetational and climatic history of Easter Island. J. Quat. Sci. 1991, 6, 85-115. [CrossRef]

14. Mieth, A.; Bork, H.R. Humas, climate or introduced rats-which is to blame for the woodland destruction of prehistoric Rapa Nui (Easter Island)? J. Archaeol. Sci. 2010, 37, 417-426. [CrossRef]

15. Mann, D.; Edwards, J.; Chase, J.; Beck, W.; Reanier., R.; Mass, M.; Finney, B.; Loret, J. Drouhgt, vegetation change, and human history on Rapa Nui (Isla de Pascua, Easter Island). Quat. Res. 2008, 69, 16-28. [CrossRef]

16. Hunt, T.L. Rethinking Easter Island's ecological catastrophe. J. Archaeol. Sci. 2007, 34, 485-502. [CrossRef]

17. Diamond, J. Collapse: How Societies Choose to Fail or Succeed; Viking: New York, NY, USA, 2005.

18. Rull, V.; Cañellas-Boltà, N.; Sáez, A.; Margalef, O.; Bao, R.; Pla-Rabes, S.; Valero-Garcés, B.; Giralt, S. Challenging Easter Island's collapse: The need for interdisciplinary synergies. Front. Ecol. Evol. 2013, 1, 3. [CrossRef]

19. Rull, V.; Cañellas-Boltà, N.; Margalef, O.; Sáez, A.; Pla-Rabes, S.; Giralt, S. Late Holocene vegetation dynamics and deforestation in Rano Aroi: Implications for Easter Island's ecological and cultural history. Quat. Sci. Rev. 2015, 126, 219-226. [CrossRef]

20. Rull, V.; Cañellas-Boltà, N.; Margalef, O.; Pla-Rabes, S.; Sáez, A.; Giralt, S. Three millennia of climatic, ecological and cultural change on Easter Island: A synthetic overview. Front. Ecol. Evol. 2016, 4, 29. [CrossRef]

21. McLaughlin, S. The Complete Guide to Easter Island; Easter Island Foundation: Los Osos, CA, USA, 2007. 
22. Van Tilburg, J.A. Easter Island: Archaeology, Ecology and Culture; Smithsonian Institution Press: Washington, DC, USA, 1994.

23. Vargas, P.; Cristino, C.; Izaurieta, R. 1000 Años en Rapa Nui. Arqueología del Asentamiento; Editorial Universitaria: Santiago, Chile, 2006.

24. Routledge, K. The Mystery of Easter Island: The Story of an Expedition; Sifton Praed, Co.: London, UK, 1919.

25. Métraux, A. Ethnology of Easter Island; Bishop Museum Press: Honolulu, HI, USA, 1940.

26. Heyerdahl, T. Easter Island. The Mystery Solved; Random House: New York, NY, USA, 1989.

27. Edwards, E.; Edwards, A. When the Universe Was an Island; Hangaroa Press: Hanga Roa, Chile, 2013.

28. Heyerdahl, T. American Indians in the Pacific: The Theory Behind the Kon-Tiki Expedition; Allen \& Unwin: London, UK, 1952.

29. Heyerdahl, T.; Ferdon, E. Reports of the Norwegian Archaeological Expedition to Easter Island and the East Pacific. Vol. 1: The Archaeology of Easter Island; Allen \& Unwin: London, UK, 1961.

30. Martinsson-Wallin, H.; Crockford, S.J. Early settlement of Rapa Nui (Easter Island). Asian Perspect. 2002, 40, 244-278. [CrossRef]

31. Kirch, P.V. Peopling of the Pacific: A holistic anthropological perspective. Annu. Rev. Anthropol. 2010, 39, 131-148.

32. Wilmshurst, J.M.; Hunt, T.L.; Lipo, C.P.; Anderson, A.J. High-precision radiocarbon dating shows recent and rapid initial human colonization of East Polynesia. Proc. Natl. Acad. Sci. USA 2011, 108, 1815-1820. [CrossRef] [PubMed]

33. Hunt, T.L.; Lipo, C.P. Late colonization of Easter Island. Science 2006, 311, 1603-1606. [CrossRef] [PubMed]

34. Nunn, P.D. Climate, Environment and Society in the Pacific during the Last Millennium; Elsevier: Amsterdam, The Netherlands, 2007.

35. Piperno, D.R.; Holst, I. The presence of starch grains on prehistoric stone tools from the humid Neotropics: Indications of early tuber use and agriculture in Panama. J. Archaeol. Sci. 1998, 25, 765-776. [CrossRef]

36. Bovell-Benjamin, A.C. Sweet potato: A review of its past, present, and future role in human nutrition. Adv. Food Nutr. Res. 2007, 52, 1-59. [PubMed]

37. Hather, J.; Kirch, P.V. Prehistoric sweet potato (Ipomoea batatas) from Mangaia Island, central Polynesia. Antiquity 1991, 65, 887-893. [CrossRef]

38. Orliac, C.; Orliac, M. The disappearance of Easter Island's forest: Over-exploitation or climatic catastrophe? In Easter Island in Pacific Context; Stevenson, C.M., Lee, G., Morin, F.J., Eds.; Easter Island Foundation: Los Osos, CA, USA, 1998; pp. 129-134.

39. Orliac, C. The woody vegetation of Easter Island between the early 14th and the mid-17th centuries AD. In Easter Island Archaeology. Research on Early Rapanui Culture; Stevenson, C.M., Ayres, W.S., Eds.; Easter Island Foundation: Los Osos, CA, USA, 2000; pp. 211-220.

40. McCall, G. Easter Island. In Encyclopedia of Islands; Gillespie, R.G., Clague, D.A., Eds.; University California Press: Berkeley, CA, USA, 2009; pp. 244-251.

41. Carlquist, S. The biota of long-distance dispersal V. Plant dispersal to Pacific Islands. Bull. Torrey Bot. Club 1967, 44, 129-162. [CrossRef]

42. Carlquist, S. Island Biology; Columbia University Press: New York, NY, USA, 1974.

43. Montenegro, A.; Avis, C.; Weaver, A. Modeling the prehistoric arrival of the sweet potato in Polynesia. J. Archaeol. Sci. 2008, 35, 355-367. [CrossRef]

44. Bourke, R.M. Sweetpotato in Oceania. In The Sweetpotato; Loebenstein, G., Thottappilly, G., Eds.; Springer: Berlin, Germany, 2009; pp. 489-502.

45. Yen, D.E. The Sweet Potato in Oceania: An Essay in Ethnobotany; Bishop Museum Press: Honolulu, HI, USA, 1974.

46. Green, R.C. Origin for the Rapanui of Easter Island before European contact: Solutions from holistic anthropology to an issue no longer much of a mystery. Rapa Nui J. 2000, 14, 71-76.

47. Green, R.C. Sweet potato transfers in Polynesian prehistory. In The Sweet Potato in Oceania: A Reappraisal; Ballard, C., Brown, P., Nourke, R.M., Harwood, T., Eds.; University of Sydney: Sydney, Australia, 2005; pp. 43-62.

48. Lawler, A. Beyond Kon-Tiki: Did Polynesians sail to South America? Science 2010, 328, 1344-1347. [CrossRef]

49. Jones, T.L.; Storey, A.A.; Matisoo-Smith, E.; Ramírez-Aliaga, J.M. Polynesians in America. Pre-Columbian Contacts with the New World; Altamira Press: Lanham, MD, USA, 2011. 
50. Roullier, C.; Benoit, L.; McKey, D.B.; Lebot, V. Historical collections reveal patterns of diffusion of sweet potato in Oceania obscured by modern plant movements and recombination. Proc. Natl. Acad. Sci. USA 2013, 110, 2205-2210. [CrossRef]

51. Muñoz-Rodríguez, P.; Carruthers, T.; Wood, J.R.D.; Williams, B.R.M.; Weitemier, K.; Kronmiller, B.; Ellis, D.; Anglin, N.L.; Longway, L.; Harris, S.A.; et al. Reconciling conflicting phylogenies in the origin of sweet potato and dispersal to Polynesia. Curr. Biol. 2018, 28, 1246-1256. [CrossRef]

52. Tromp, M.; Dudgeon, J.V. Differentiating dietary and non-dietary microfossils extracted from human dentaal calculus: The importance of sweet potato to ancient diet on Rapa Nui. J. Archaeol. Sci. 2015, 54, 54-63. [CrossRef]

53. Moreno-Mayar, J.V.; Rasmussen, S.; Seguin-Orlando, A.; Rasmussen, M.; Liang, M.; Flåm, S.T.; Lie, B.A.; Gilfillan, G.D.; Nielsssen, R.; Thorsby, E.; et al. Genome-wide ancestry patterns in Rapanui suggest pre-European admixture with Native Americans. Curr. Biol. 2014, 24, 2518-2525. [CrossRef]

54. Thorsby, E. Genetic evidence for a contribution of native Americans to the early settlement of Rapa Nui (Easter Island). Front. Ecol. Evol. 2016, 4, 118. [CrossRef]

55. Fehren-Scmitz, L.; Jarman, C.L.; Harkins, K.M.; Kayser, K.M.; Popp, B.N. Genetic ancestry of Rapanui before and after European contact. Curr. Biol. 2017, 27, 3209-3215. [CrossRef]

56. Storey, A.A.; Ramírez, J.M.; Quiroz, D.; Burley, D.V.; Addison, D.J.; Walter, R.; Anderson, A.J.; Hunt, T.; Athens, J.S.; Huynen, L.; et al. Radiocarbon and DNA evidence for a pre-Columbian introduction of Polynesian chickens to Chile. Proc. Natl. Acad. Sci. USA 2007, 104, 10335-10339. [CrossRef]

57. Thomson, V.A.; Lebrasseur, O.; Austin, J.J.; Hunt, T.L.; Burney, D.A.; Denham, T.; Rawlence, N.J.; Wood, J.R.; Flink, L.G.; Linderholm, A.; et al. Using ancient DNA to study the origins and dispersal of ancestral Polynesian chickens across the Pacific. Proc. Natl. Acad. Sci. USA 2014, 111, 4826-4831. [CrossRef]

58. Matisoo-Smith, E.; Ramirez, J.M. Human skeletal evidence of Polynesian presence in South America? Metric analyses of six crania from Mocha Island, Chile. J. Pac. Archaeol. 2010, 1, 76-88.

59. Malaspinas, A.-S.; Lao, O.; Schroeder, H.; Rasmussen, M.; Raghavan, M.; Moltke, I.; Campos, P.F.; Sagredo, F.S.; Rasmussen, S.; Gonçalves, V.F.; et al. Two ancient human genomes reveal Polynesian ancestry among the indigenous Botocudos of Brazil. Curr. Biol. 2014, 24, R1035-R1037. [CrossRef]

60. Rull, V.; Lara, A.; Rubio-Inglés, M.J.; Giralt, S.; Gonçalves, V.; Raposeiro, P.; Hernández, A.; Sánchez-López, G.; Vázquez-Loureiro, D.; Bao, R.; et al. Vegetation and landscape dynamics under natural and anthropogenic forcing on the Azores Islands: A 700-year pollen record from the São Miguel Island. Quat. Sci. Rev. 2017, 159, 155-168. [CrossRef]

61. Rull, V. The EIRA database: Last Glacial and Holocene radiocarbon ages from Easter Island's sedimentary records. Front. Ecol. Evol. 2016, 4, 44. [CrossRef]

62. Haberle, S.G.; Atkin, G. Needles in a stayhack: Searching for the sweet potato (Ipomoea batatas (L.) Lam.) in the fossil pollen record. In The Sweet Potato in Oceania: A Reappraisal; Ballard, C., Brown, P., Nourke, R.M., Harwood, T., Eds.; University of Sydney: Sydney, Australia, 2005; pp. 25-33.

63. Horrocks, M.; Wozniak, J.A. Plant microfossil analysis reveals disturbed forest and a mixed-crop, dryland production system at Te Nui, Easter Island. J. Archaeol. Sci. 2008, 35, 126-142. [CrossRef]

64. Horrocks, M.; Baisden, T.; Flenley, J.; Feek, D.; Love, C.; Haoa-Cardinali, S.; González Nualart, L.; Edmunds Gorman, T. Pollen, phytolith and starch analyses of dryland soils from Easter Island (Rapa Nui) show widespread vegetation clearance and Polynesian-introduced crops. Palynology 2016, 41, 339-350. [CrossRef]

65. Cummings, L.S. A review of recent pollen and phytolith studies from various contexts on Easter Island. In Easter Island in Pacific Context; Stevenson, C.M., Lee, G., Morin, F.J., Eds.; Easter Island Foundation: Los Osos, CA, USA, 1998; pp. 100-106.

66. Horrocks, M.; Baisden, W.T.; Nieuwoudt, M.K.; Flenley, J.; Feek, D.; González Nualart, L.; Haoa-Cardinali, S.; Edmunds Gorman, T. Microfossils of Polynesian cultigens in lake sediment cores from Rao Kau, Easter Island. J. Paleolimnol. 2012, 47, 185-204. [CrossRef]

67. Horrocks, M.; Baisden, W.T.; Flenley, J.; Feek, D.; González Nualart, L.; Haoa-Cardinali, S.; Edmunds Gorman, T. Fossil plant remains at Rano Raraku, Easter Island's statue quarry: Evidence for past elevated lake level and ancient Polynesian agriculture. J. Paleolimnol. 2012, 48, 1-17. [CrossRef] 
68. Cañellas-Boltà, N.; Rull, V.; Sáez, A.; Margalef, O.; Bao, R.; Pla-Rabes, S.; Blaauw, M.; Valero-Garcés, B.; Giralt, S. Vegetation changes and human settlement of Easter Island during the last millennia: A multiproxy study of the Lake Raraku sediments. Quat. Sci. Rev. 2013, 72, 36-48. [CrossRef]

69. Butler, K.R.; Flenley, J.R. The Rano Kau 2 pollen diagram: Palaeoecology revealed. Rapa Nui J. 2010, $24,5-10$.

70. Chamberlin, T.C. The method of multiple working hypotheses. Science (Old Ser.) 1980, 15, 92-96, reprinted 1965, 148, 754-759.

71. Platt, J.R. Strong inference. Science 1964, 146, 347-353. [CrossRef] [PubMed]

72. Popper, K.R. The Logic of Scientific Discovery; Basic Books: New York, NY, USA, 1959.

(C) 2019 by the author. Licensee MDPI, Basel, Switzerland. This article is an open access article distributed under the terms and conditions of the Creative Commons Attribution (CC BY) license (http://creativecommons.org/licenses/by/4.0/). 